\title{
Exploring Secondary School Students' Stances on the Predictive and Explanatory Power of Science
}

\section{Berry Billingsley $^{1}$ (D) Mehdi Nassaji $^{1}$}

Published online: 27 February 2019

(C) The Author(s) 2019

\begin{abstract}
There are widespread calls for school education to put more emphasis on developing students' appreciation of the power and limitations of science. Without effective teaching, there is a risk that sensationalist media claims will unduly influence students' perceptions of the power of science to already explain and predict aspects of our daily lives. Secondly, schools have a role in preparing students for a future in which they are likely to work and play alongside increasingly humanlike machines. The study reported here assessed the feasibility of a survey to discover students' stances on the predictive and explanatory power of science in relation to personality, behaviour and the mind The study forms part of a larger project that seeks to identify ways that schools can develop students' epistemic insight when they consider big questions about the nature of reality and human personhood. Beginning with a broad conceptualisation of personhood designed to pick up on questions in the science-religion dialogue, we drew on interviews and focus groups with students in upper secondary school to formulate a set of statements that seemed to be effective in stimulating discussion about the power and limitations of science. The questionnaire was administered to 311 secondary students. Students' responses indicate that they were engaged by the theme and that they were generally not working with a secure overarching scientistic or nonscientistic framework. When we grouped students according to how they responded to the narrower theme of personality and behaviour, one in five of the cohort was labelled as strongly scientistic. We also found that in their comments at different points in the survey, the majority of students expressed ideas and everyday phrases associated with scientism. The article concludes with implications for future research and further recommendations for teachers.
\end{abstract}

\section{Introduction}

There are two contexts for the current study. The first context is a concern by the authors that there are factors in schools that negatively affect students' attitudes to asking and exploring

Berry Billingsley

berry.billingsley@ canterbury.ac.uk

Mehdi Nassaji

mehdi.nassaji@canterbury.ac.uk

1 Faculty of Education, Canterbury Christ Church University, North Holmes Road, Canterbury, Kent CT1 1QU, UK 
Big Questions and their understanding of the relationships between science and religion. The second and broader context is a call for school education and particularly science education to put more emphasis on developing students' epistemic insight and in particular, their appreciation of the power and limitations of science. These matters prompted the current study which aimed to develop a questionnaire that can be used to explore upper secondary school students' stances on the predictive and explanatory power of science in an important and original context, namely, the Big Question of human personhood.

We characterise Big Questions in three ways: Big Questions are questions about human personhood and the nature of reality. Secondly, Big Questions are questions on which both science and religion seem to have something to say - a characteristic which makes them socially sensitive and also means they bridge the subject border around science. Van Inwagen (2018) gives the following examples of Big Questions, which have religious, scientific and metaphysical dimensions: "Why is there something rather than nothing?"; "Why are there rational beings?"; "Are we physical or nonphysical beings?" and "Have we free will?". Thirdly, we characterise Big Questions as questions that bridge science, religion and the humanities more broadly. This provides a wider umbrella under which we can develop and provide teachers with examples of questions that can be used as stepping stones to develop students' epistemic insight. These include questions that bridge science and religion together with questions that bridge science-and-history, science-and-the arts and science-and-metaphysics. In doing so, we aim to support teachers with a range of ways to develop students' epistemic insight relating to Big Questions.

The current study was motivated by the findings of research that examined school students' attitudes to asking and exploring Big Questions and their understanding of how science and religion relate. This revealed that while students' experiences in education vary considerably, there are systematic pressures and barriers that prevent students and teachers from raising topics that are perceived to be religiously sensitive and/or off-topic. These, together with other pressures such as teachers' areas of professional interest dampen students' expressed interest in Big Questions and limit their opportunities to develop the epistemic insight they need in order to access a range of ways of thinking about the relationships between science and religion, including positive ways. By epistemic insight, we refer broadly to knowledge about knowledge and particularly to knowledge about disciplines and how they interact. The term was introduced as a way to highlight that without effective teaching, students are unlikely to develop the understanding they need to explain that and why science and religion do not necessarily conflict (Billingsley et al. 2013).

Turning to the teaching of epistemology in schools, Duschl and Osborne (2002, p. 39) explained that teaching "needs to accomplish much more than simply detailing "what we know" and that students need to engage with "the construction and evaluation of scientific knowledge". More recently, Osborne (2013, p. 265) stated again that students should learn the content and procedures of science while also developing "an epistemic knowledge of how such procedures warrant the claims that scientists advance". Studies to date of how students construct their personal epistemologies have mostly explored and compared students' perceptions of school and real versions of each of the disciplines (Sandoval 2016). For example Zhai et al. (2014) found that primary school students can already point to differences between real and school science, saying that real scientists work alone without a teacher and do more dangerous investigations.

The aims for this study were firstly to discover the feasibility of a survey to discover students' stances on the power and limitations of science in relation to the big question of how to understand human personhood. 
To meet this aim, we wanted a questionnaire that upper secondary school students could understand without any additional explanation. Secondly, we intended to use the survey for a preliminary study to look at the extent to which students seem to each have a consistent stance across a selection of topics. This set of topics and the questionnaire would then be a tool that can be used by teachers and researchers to form a picture of the range of stances that students take up within a given cohort. The findings could in turn inform teaching designed to develop students' capacities to critically examine their own and other people's stances and help students where appropriate to progress from narrow absolutist misperceptions. By researching for the first time, students' stances on the predictive and explanatory power of science in the context of human personhood, we begin to ascertain the potential of this Big Question as a context that could help teachers to develop students' criticality about the power and limitations of science. The increasing prominence of humanlike machines gives this work a new urgency because of the questions that artificial intelligence raises (Cath et al. 2018).

\section{Theoretical Background}

\subsection{Big Questions}

The starting point for our current study was to investigate students' perceptions of what science says about human personhood. We chose this Big Question because it raises issues that are likely to be of widespread interest. It also has the advantage that it creates opportunities to talk with school students about the power and limitations of science while not directly referencing the 'creation-evolution' controversy (Hayward 1998; Wysong 1976) - a topic that science teachers and students often prefer to avoid in lessons (Billingsley et al. 2014, 2016).

Science education aims to help students to make progress towards more scientific ways of thinking (Taber 2009; White and Gunstone 1992) and it is important in our view that students have sessions where they become immersed in scientific ways of thinking and working. With this said, it is also important that they consider the implications of scientific ideas in relation to their wider, everyday beliefs and experience. In particular, secondary school students' experiences in the science classroom are affected by a firm subject boundary (Bernstein 2000), and their enquiries in science lessons are frequently confined to looking at questions where the conclusions are established and uncontroversial (Kötter and Hammann 2017). In England, in the current context, the vast majority of schools provide religious education and this subject has responsibility for teaching about the Big Questions and the relationships between science and religion. Students' religious education teacher is not usually their science teacher and students rarely if ever have opportunities to explore Big Questions with a specialist science teacher (Billingsley and Nassaji 2017). We surmised that these pedagogical boundaries and pressures could potentially have unintended influences on students' perceptions of how science approaches questions about human personhood and the nature of reality - and in some cases, on students' own stances on the explanatory and predictive power of science in relation to these Big Questions.

\subsection{Uncritical Scientism}

Uncritical scientism is a stance, drawing on Bas Van Fraassen (2008, p. 62) explanation that stances are a mixture of beliefs and attitudes and "a good deal more". Van Fraassen referred to materialism and empiricism as stances. Kidd (2016) added scientism as a stance, suggesting that it involves attitudes and beliefs and that a scientistic person is likely to be closed to the possibility of there being forms and 
sources of knowledge, evidence, enquiry or reason that are not scientific in character. Uncritical scientism has a family resemblance to scientism, and some authors associate scientism with a lack of criticality (see for example Miller 2015). Our label "uncritical" scientism makes this aspect explicit as the notion that scientism can be accepted uncritically is central to our use of the construct in education. Thus, an important criterion for uncritical scientism is that the student holds this stance uncriticallywithout an appreciation that there is a range of views on the power and limitations of science and that scientism is a controversial stance to take. We return to this use of the term shortly.

Stenmark (1997) suggested that scientism includes a tendency to say that in the future, science will provide a full explanation of how nature behaves using simple "scientific" language. In our model of pedagogical pressures, a student might form this conclusion while influenced by simplified versions and interpretations of scientific ideas (Billingsley 2013; Jamieson and Radick 2013). Students' perceptions of the power and limitations of science to model reality are also influenced by their experiences of pedagogically engineered practical work - whereby questions asked of reality are investigated using a one-off experiment that is designed to teach an established scientific concept (Billingsley 2017). Stenmark (1997) also suggested that scientism promotes a narrow view of what science is, focused on the natural sciences or in some cases even more narrowly on the materialphysical sciences, as well as the view that questions explored by other disciplines should be dismissed. As we noted earlier, once they are in secondary school, the subject boundary in curriculum science filters the topics and questions about reality that students explore in science lessons for reasons and in ways that may not be apparent to students (Billingsley 2017). These simplifications of what science says about reality, pedagogically engineered investigations and subject boundary filters have the potential to prompt some students to underappreciate the complexity of reality and to overestimate the extent to which science has ready access to predicting and explaining how reality works.

As we indicated above, an important criterion for uncritical scientism is that the student adopts this stance uncritically. In an interview study that asked students aged 10 years old how they perceived the nature of science, there were several who made comments that conceivably reflected an uncritically scientistic stance (Billingsley and Hardman 2017, p. 61):

Well, if it wasn't for science we wouldn't know much about the world or anything, really.

I only believe science and logical answers and theories.

I think the universe was up to science and science did everything.

There is a basis to say that secondary school science teachers resist talking about the nature, power and limitations of science and that students have few opportunities to develop their criticality (Konnemann et al. 2016; Kötter and Hammann 2017). We hope that surveys and studies like the present one will motivate and help teachers to develop pedagogies to increase students' understanding and criticality. One way that teachers and researchers can discover the extent to which students' stances on the predictive and explanatory power of science are held critically or uncritically is to ask a class to evaluate and report their own learning at the end of a workshop that identifies and discusses some of the stances that people take.

\subsection{Pressures and Barriers that Foster Uncritical Scientism}

Some of the pressures and barriers that can foster uncritical scientism are:

- Entrenched compartmentalisation: When students begin secondary school they typically enter a system in which the compartmentalisation of science is entrenched. By entrenched 
compatmentalisation, we mean that organisational, social and pedagogical practices associated with subject compartmentalisation have become habits and now dictate students' and teachers' expectations about what should happen in the classroom (Billingsley 2017). Students become acclimatised to a kind of science learning in which questions and distractions from other disciplines are blocked out, thus preventing them from seeing how questions asked in other disciplines shape scientific practice and curiosity. The pressure of a programme that is packed with teaching scientific concepts and several decades of entrenched compartmentalisation means that science teachers typically have little or no opportunity or sufficient motivation to find out whether and how their teaching is affecting students' wider thinking (Billingsley et al. 2018; Osborne and Collins 2001).

- Teaching science via fragmented topics in secondary school: In England and most other countries, the content in school science is divided into self-contained topics. A typical school science handout for year 8 (age 12 years old) lists ten topics for the year with one being, "Motion and Pressure - covers speed, distance and velocity time graphs, pressure in solids, liquids and gases, and turning forces" (Hawkins 2017). Topics are given equal time and look similar in the textbook, masking the epistemological distinctiveness across the fields of science. In a manner of speaking, the questions and methods associated with science are "epistemologically homogenised".

- Recipe investigations: To help students learn and consolidate conceptual knowledge, teachers widely make use of so-called cookbook or recipe investigations (Tho and Yeung 2016). The apparatus and instructions are pedagogically engineered to help students arrive at a concept or relationship described in their course (Billingsley, 2017). An observation study of secondary school practical work revealed that sessions were focused on concepts with little or no work on why these are appropriate methods or whether these methods have limitations (Abrahams and Millar 2008). By the time students enter upper secondary school and with exams looming, both teachers and students are focused on whether experiments "work" and the question that students are asking is not "What happens if?"” but is rather "Is this right?" (Longshaw 2009, p. 93).

- A lens of simplification: By upper secondary school, students have experienced many years of pedagogical engineering repeated across multiple topics - combined with simplified scientific explanations in textbooks. This affects what students suppose that science says about reality, and for many students it also affects how they perceive the nature of the world and its amenability to science - so in genetics for example, students develop an "“everyday' conception of genes as small, trait-bearing, particles" (Lewis and Kattmann 2004, p. 195).

- Exaggerated headlines: As they progress through school students are increasingly likely to have seen media headlines and stories that suggest that scientists are on the brink of having a sufficient model and explanation for particular phenomena in a given context of everyday life. Some examples are, "GCSE results 'influenced by children's genes, not teaching", (Paton 2013); "New blood test targets depression" (Roberts 2016); "scientists discover a chatty gene" (Waghorn 2016); "Scientists prove chocolate "better than being in love"" (Freeman 2002); and the reported discovery of a "warrior gene" (Cheung 2018). The way that science courses and examinations are currently structured means that students are unlikely to spend lesson time critically reflecting upon these kinds of headlines.

\subsection{Reviewing the Literature for Themes}

To identify topics to explore in this study, we researched scholarly perspectives relating to human personhood by reviewing books and articles in science and religion on this Big 
Question. In parallel, we conducted semi-structured interviews, focus group discussions and workshops in eight schools looking for effective ways to prompt students to talk about ways that science interacts with their own and other people's beliefs about human personhood.

There are multiple perspectives on what to believe about human personhood in the literature and we only discuss a few here, filtered by our interest in providing schools with strategies that they can use to develop students' understanding of the ways that science and religion relate. There is a widespread belief among both religious and nonreligious students that people have a soul and a significant proportion of these people also believe that the soul exists separately to the material person (Mansell 2016). A number of authors including Murphy and Brown (2007) link this conception of the person to Cartesian Dualism - but whereas in Descartes' proposal, it is the mind (the "thinking thing") that is separate to the material person; in popular culture, it is widely said to be the soul. Another conception shares aspects of personhood between the mind and soul (Bloom 2004). Without delving too deeply into these discussions, there are many reasons to reject the notion of a separate nonmaterial entity that is the source of popular aspects of personhood like free will. One of these is that a physical probe placed into a specific area of the brain or brain damage to that area changes how the mind behaves (Fuchs 2004). One commentator suggested that, "We have seen that neurological and medical evidence strongly indicates that our memories, emotions, thoughts and indeed our very personalities reside in the physical particles of the brain or, more precisely, in the ways those particles interact" (Stenger 2007, p. 103). Some authors have argued that there is no limit to the power of science to address and one day resolve questions about human personhood. Frances Crick argued that the conclusion of neuroscience is that,

You, your joys and your sorrows, your memories and your ambitions, your sense of personal identity and free will, are in fact no more than the behaviour of a vast assembly of nerve cells and their associated molecules (Crick 1994, p. 3).

Sam Harris $(2012$, pp. 5, 9) made a similar case, arguing that, "Free will is an illusion. Our wills are simply not of our own making ... your brain has already determined what you will do". Speaking more broadly, Atkins wrote that "there is no reason to expect that science cannot deal with any aspect of existence", "that reductionist science is omnicompetent" and that "science has never encountered a barrier that it has not surmounted or that we can at least reasonably suppose it has the power to surmount" (Atkins 1995, pp. 123-125). Rejecting both the notion of a mind that has no relationship with matter and the conclusion that the material sciences can one day provide a sufficient explanation of human personhood, Polkinghorne stated that:

I believe that we human beings are psychosomatic unities, a package deal with mind and matter in inseparably complementary relationship to each other. It is a conclusion that would not have surprised the writers of the Bible. It has often been acknowledged that they thought of human beings as "animated bodies", rather than "incarnated souls".

This stance is reflected in the following general statement of the way that reality works when Polkinghorne asserted that, "Science's account of causal properties is patchy and does not imply the closure of the universe to other forms of causal influence" (Polkinghorne 2006, p. 97). Polkinghorne explained the innovation he hoped to see for science in future, saying:

My hope and expectation for the science of the twenty first century is that an entirely new and fertile way of thinking about nature will develop, complementing the reductionist/constituent way in which we have 
thought over the last 350 years. The physics of past generations was based on a bits and pieces approach, thinking in terms of the exchange of energy between particles. That approach was certainly not wrong, but it has turned out not to be wholly adequate. We need also to be able to think holistically in terms of overall behaviour, as well as reductively in terms of parts (Polkinghorne 2004, p. 594).

This means that some people's idea of soul can seem to be incompatible with their understanding of science for a number of reasons. One is that what to believe about the soul has largely become linked to Descartes' beliefs about the mind, the notion of a separate nonmaterial essence of the person that directs daily behaviour. Secondly, some authors' metaphysical positions on the nature of reality seem to resonate with their stances on personhood. This issue is also complex because definitions of science vary and some people are using the term narrowly to refer to physical (or physical and chemical) processes, whereas some others characterise science more broadly. Even so, we conclude that there is metaphysical sensitivity around the question of whether science can now or will ever provide a complete explanation of human personhood and the nature of reality. Further, the question of what to believe about causality seems to be widely discussed across both contexts. This also provides us with ideas about how to characterise a scientistic stance for this Big Question. It is consistent with science to say that human personhood will one day be fully explained by physical/biological processes, but this is not a necessary commitment in science and reflects a scientistic stance.

\subsection{Research Questions}

This leads to a circumspection that because of the way that subjects are organised and taught in schools, students are at risk of developing a perception that reality is more readily accessed and described by school-science than it really is. We also surmise that pedagogies and contexts, which would help counter misperceptions about the power of science to access, predict and explain the nature of reality and human personhood are squeezed out by these same organisational and pedagogical pressures and barriers. In the light of these considerations our research questions are:

1. To what extent are students in upper secondary school engaged by questions about the explanatory and predictive power of science on matters to do with the Big Question of personhood-is this theme interesting and meaningful?

2. To what extent are students' responses tending towards a scientistic stance and to what extent are they tending to a nonscientistic stance?

3. Is it feasible to use students' responses to the statements to define and identify a group of students who tend to take a scientistic stance across several topics and those who take a nonscientistic stance? And if yes, what else can be drawn from the data about the characteristics of the students in each group?

\section{Method}

For the next stage of the project, we gathered stimulus materials, including newspaper headlines and magazines and the scripts of TV dramas, which made sensationalist claims about the power of science to explain and predict an everyday aspect of life and/or the person. In four schools, we presented these materials to students in year 9-11 (aged 13-15) during an exploratory survey of open-ended questions with a class of students, in semistructured interviews with 20 students and in four focus group discussions. In four other 
schools we ran a workshop for students that introduced and discussed a TV drama in which a boy's violent behaviour was attributed by his defence lawyer to the so-called warrior gene. We analysed the data to ascertain which stories, questions and headlines most reliably prompted students to talk about the explanatory and predictive power of science. We also gradually replaced the media headlines with statements that students made in their own language and then tested these statements with other students. Based on this research, we constructed a set of six statements. Via our trials of differently worded statements, we found that expressions of scientism tended to prompt students into revealing their own stances on the power and limitations of science. It was more difficult to prompt students into expressing their own stances using statements that reflected nonscientistic views. We list all the statements we selected for the survey at the end of this section. Throughout this article, we have replaced students' real names with pseudonyms.

The questionnaire was administered to groups of students in eight secondary schools in England. The criteria for selecting schools were achieving a demographic representation in terms of geography and type of school. The school selection also reflected our aim to have a gender balance across the whole cohort. The 311 participants were in year 10 (aged about 14) and nearing the end of compulsory education, at which point they can opt in or out of further study of science. As such this is an important point in children's education at which to assess their understanding of the power and limitations of science. The practical arrangements for students to fill in the online survey were organised by teachers who in turn were selected by the head teacher (our contact in each school). We liaised with each teacher to ensure that the participating group would be a full class or an existing cohort of students during a supervised session, to reduce the risk of self-selection. Tables 1 and 2 give the numbers from each school and other details.

We constructed four statements by analysing students' responses to materials discussing the power of science to explain and/or predict personality, behaviour and the choices that people make. The preliminary work that led us to these statements included asking a class of students in year 10 (age 15) to discuss a headline in the Telegraph that "GCSE results 'influenced by children's genes, not teaching" (Paton 2013). Sarah responded that:

You can't change the fact that genes are [responsible for] $51 \%$ of your intelligence. [...] I agree with the scientist. I know it's sad but I really think that genes are the determining factor.

Table 1 Cohort profiles for the survey

\begin{tabular}{lcrlll}
\hline & Frequency & Percent & Gender & Location & Type of school \\
\hline School A & 33 & 10.6 & Mixed & Urban & Independent \\
School B & 14 & 4.5 & Girls & Suburban & Independent faith school \\
School C & 26 & 8.4 & Mixed & Suburban & State funded \\
School D & 21 & 6.8 & Mixed & Urban/inner city & State funded \\
School E & 102 & 32.8 & Boys & Urban & State funded \\
School F & 16 & 5.1 & Mixed & Suburban & State funded \\
School G & 10 & 3.2 & Mixed & Inner city & Vol. aided \\
School H & 85 & 27.3 & Girls & Suburban & Independent \\
Missing & 4 & 1.3 & & & \\
Total & 311 & 100.0 & & & \\
\hline
\end{tabular}


Table 2 Cohort profiles for the survey (gender)

\begin{tabular}{lcr}
\hline & Frequency & Percent \\
\hline Full cohort & 311 & 100.0 \\
Male & 153 & 49.2 \\
Female & 155 & 49.8 \\
Missing gender & 3 & 1.0 \\
\hline
\end{tabular}

Nasrin, a year 10 student taking part in an interview study, stated that:

Genetics can already tell us a lot about what we will look like and some our characteristics. I believe that one day we will be able understand how personalities are formed.

Amin, another interview participant, said in contrast that:

Science tells you how clever the human body is and what it does, like the atoms inside it help you to survive or reproduce, but it doesn't tell you why you make decisions and why you become the person that you do become through life like you might learn in RE or in Ethics and other stuff like that.

There were also some students in the interview study who seemed to find the position they associated with science as credible but also as one that they resisted for themselves. Raminder, for example, stated that:

I'd still believe it's free will instead of just a mass of atoms, but I think it's because I like to believe that. I like to believe it's free will because then it shows that [ . . ] there's more of a purpose to life.

Kiara (also age 15 years old) expressed the view that what we say to each other and what we truly believe need not be the same, saying:

I think there is a physical explanation for the choices that you make, but I don't think that that's the one that's going to help you to help people make different choices, or to understand why they actually made the choices...I think it's possible to explain how we act pretty much entirely in terms of neurons and chemicals. But, I think you can also explain it in a more helpful way when you're speaking to a person $[\ldots]$ as their experiences and how they feel about things.

We constructed one of the final groups of statements by drawing on students' responses to a selection of media reports on advances in neuroscience. The stimulus materials included the headline, "Scan that says it's true love: Brain experts say they can tell what stage of romance someone is at by looking at MRI results" (Spencer 2015). One of our guiding reference points in the literature for this theme was a study by Racine et al. (2010), who concluded that neuroessentialism is an emerging trend in media interpretations of neuroimaging. The authors explained that neuroessentialism refers to depictions of the brain as the essence of a person, with the brain being a synonym for soul. We chose and developed a sixth statement on the basis that during these studies many of the participating students introduced comparisons between the brain and a computer. Phoebe used this analogy when explaining why her view is that we will one day have a complete explanation of how the mind works:

I think through science in a century or so it would be possible as the mind is basically like a supercomputer sending messages around the brain and it's made up of millions of connections. 
We also recorded this comment by Richard, talking about whether we can one day predict human behaviour scientifically:

I think it is possible because the mind ... in a way, we are like robots ... I think it is possible to predict what the mind is going to do.

Robots and computers have for some time been associated with simulating/replicating rational thinking, smartness and intelligence (Colburn 2015), There are also references to the brain as having been hardwired by evolution (Grossi 2017). Biologist and Christian, Denis Alexander (2013, p. 12) was asked about the use of analogy at the end of a recorded talk and made the comment that:

The way that science is communicated in the public domain can be much influenced by the language used and I would agree with Bill that genetics is often communicated loaded with deterministic computer language. The language of computation can be useful in a limited kind of way but I think you are right that we should be wary.

An internet search produced many examples of authors comparing the brain and a computer in the media. Writing with the headline "Face it! Your Brain is a Computer", Professor of psychology and neural science, Gary Marcus (2015) asserted in the New York Times that:

\footnotetext{
...there is a popular argument that human brains are capable of generating emotions, whereas computers are not. But while computers as we know them clearly lack emotions, that fact itself doesn't mean that emotions aren't the product of computation. On the contrary, neural systems like the amygdala that modulate emotions appear to work in roughly the same way as the rest of the brain does, which is to say that they transmit signals and integrate information, and transform inputs into outputs. As any computer scientist will tell you, that's pretty much what computers do.
}

We added a seventh statement designed to probe school students' attitudes towards exploring questions in this area.

The statements were put into the format of a computer-based questionnaire and were tested by a group of students, including some who were younger than our target group. A researcher observed students working on the questionnaire and asked students at the end of the process to describe their experiences of filling it in. Students reported favourably on their experience of responding to the questions in terms of their length, repetitiveness and complexity. They commented that having tick-box and multiple-choice questions combined with extra space to write thoughts made the layout feel comfortable, but also that they wanted the response options repeated more often as sometimes the question and the options were not together on their screens. We made further changes accordingly. The final statements are:

- One day science will be able to tell us how our personalities are formed.

- One day science will be able to predict how a person will behave at every moment.

- A person's behaviour is something that science will never be able to fully explain.

- Humans can make choices about how to behave.

- Human brains are like computers, they run on programs.

- The brain is what makes you, 'you'.

- I am interested in thinking about what it means to be human. 
Alongside each statement, students were given the options: Strongly agree, Agree, Neither agree nor disagree, Disagree, Strongly disagree. An odd number of categories is more appropriate in this study as we would like to know if school students are neutral on the topics we are exploring (Babakus and Mangold 1992). In addition to statements designed to discover students' attitudes to the power and limitations of science, we included some exploratory questions relating to other research themes which we do not report here such as "In which school lessons do you feel you learn the most about being human?" We do not see these additional statements as a disadvantage in the context of this study. Further, in the cases of these other questions, students were offered nouns as options (such as subject names) rather than levels of agreement and we surmised that this visual variety might help to prevent students from falling into a pattern of marking their questionnaires without reflecting on the questions. To reduce the possibility that students selected a position on a statement which they had not understood, the options with each statement also included, "I do not understand the question". There was a box where students could enter a comment after each of the statements.

The introduction to the survey explained to students that their answers would be confidential, that participation was voluntary and that they could skip any questions they did not want to answer. Students were advised that they could close the survey and their data would be discarded and that once they clicked "submit" they were giving permission for their data to be used in the study.

\section{Results}

Statistical analyses were carried out with the Statistical Package for the Social Sciences (SPSS, v22). Selected comments are also included in our discussion to illustrate and contrast scientistic and nonscientistic stances and to give examples of students' reasoning when responding to the statements. We have used each student's record number in the survey rather than pseudonyms to anonymise the survey comments.

1. To what extent are students in upper secondary school in this age group engaged by questions about the explanatory and predictive power of science on matters to do with the Big Question of human personhood - is this theme interesting and meaningful?

2. To what extent are students' responses tending towards a scientistic stance and to what extent are they tending to a nonscientistic stance?

3. Is it feasible to use students' responses to the statements to define and identify a group of students who tend to take a scientistic stance across several topics and those who take a nonscientistic stance? And if yes, what else can be drawn from the data about the characteristics of the students in each group?

\subsection{Interest in Questions about Human Personhood and the Explanatory Power of Science}

Our first research question was the extent to which students in upper secondary school are engaged by questions about the explanatory and predictive power of science on matters to do with human personhood and in particular, here, the personality, the brain, personality and behaviour, as well as whether this Big Question is interesting and meaningful. We found that 
nearly $60 \%$ of the cohort strongly agreed or agreed with the statement "I am interested in thinking about what it means to be human", with fewer than one in five expressing disinterest. Further, the response rate was broadly consistent throughout the survey and every participant added comments explaining their responses to at least one statement, suggesting a generally good level of engagement from beginning to end. Looking at the responses to all the statements in the survey, the proportions of students who ticked "I don't understand the question" was typically at or below 5\%. These are indications that the survey statements generally made sense to students.

For all statements above, in order to check whether they were revealing a range of stances, we constructed Table 3, which shows a sample of students' comments for each of the statements. These comments and some additional examples are discussed further in the sections that follow to illustrate the range of stances that emerged in students' responses to the statements and what the survey can reveal about students' ways of thinking about the power and limitations of science.

\subsection{Scientistic and Nonscientistic Stances}

We sought next to discover the extent to which students' responses were tending towards a scientistic stance and to what extent they were tending to a nonscientistic stance. In response to the statement that "One day science will be able to tell us how our personalities are formed", around $40 \%$ of the cohort strongly agreed or agreed while just over $25 \%$ disagreed or strongly disagreed. A smaller proportion (13.1\%) strongly agreed or agreed that "One day science will be able to predict how a person will behave at every moment" with near to $70 \%$ of the cohort disagreeing or strongly disagreeing. Nearly $60 \%$ strongly agreed or agreed with a corresponding statement that "A person's behaviour is something that science will never be able to fully explain".

Comments by some who agreed that behaviour is ultimately predictable included:

Science can already explain people's behaviour through their genes. It's only a matter of time before we have all the pieces of the proverbial behavioural puzzle (M-240).

In their reasons for rejecting the statement many students picked up on the phrase "at every moment" saying the claim is too ambitious: "this is too extreme for me to agree", "it is mathematically impossible to predict anyone's actions $100 \%$ unless you know absolute everything that has ever happened to them" (M-287). For many students, the barrier to predicting behaviour was an intuitive sense that there is a "human impulsiveness" and/or a "randomness" which is beyond science to foresee. Some examples follow: "Although this could be possible, I believe that people make splitsecond decisions and I don't think you would be able to predict these" (M-213); "Humans are unpredictable and can change their mind in a matter of seconds" (M-144); "You can change instantly" (M-23); "People do impulsive things, things that nobody can predict" (M-157). A few comments referred to an overarching nonscientistic stance. These included, "It is always up to the mind to control what you do" (M-61).

The statement that "Humans can make choices about how to behave" was useful in focus groups as a way to prompt discussion. In the survey, we found that a very high proportion of students $(83.6 \%)$ agreed with the statement while only $6.1 \%$ disagreed. Students' comments among those who agreed with the statement in some cases made a clear reference in a comment to a nonreductionist view of mind - such as, "[yes] we have free will and a conscience" (M-42). Some other comments are difficult to interpret such as, "[yes] as you 
Table 3 Sample of Students' comments

\begin{tabular}{|c|c|c|c|}
\hline Statement & $\begin{array}{l}\text { Comments (Strongly agree } \\
\text { or agree) }\end{array}$ & $\begin{array}{l}\text { Comments (Neither agree } \\
\text { nor disagree) }\end{array}$ & $\begin{array}{l}\text { Comments (Disagree or } \\
\text { Strongly disagree) }\end{array}$ \\
\hline $\begin{array}{l}\text { The brain is what } \\
\text { makes you, 'you' }\end{array}$ & $\begin{array}{l}\text { Yes, as the brain control } \\
\text { everything in your body } \\
\text { and feelings. Without } \\
\text { your brain you'd be dead. }\end{array}$ & $\begin{array}{l}\text { In a sense, depends on how } \\
\text { easily your brain is } \\
\text { influenced by the } \\
\text { environment. }\end{array}$ & $\begin{array}{l}\text { It's not all about the brain, in } \\
\text { my opinion it's about } \\
\text { your soul (a part which } \\
\text { lives outside you) which } \\
\text { makes you you }\end{array}$ \\
\hline $\begin{array}{l}\text { One day science will } \\
\text { be able to tell us } \\
\text { how our } \\
\text { personalities are } \\
\text { formed }\end{array}$ & $\begin{array}{l}\text { Science makes amazing } \\
\text { discoveries every day and } \\
\text { will no doubt be able to } \\
\text { tell us everything about } \\
\text { our personalities in the } \\
\text { future. }\end{array}$ & $\begin{array}{l}\text { I believe in some form of } \\
\text { determinism, kind of. So } \\
\text { it's not necessarily a } \\
\text { 'choice' - just random } \\
\text { enough to be almost } \\
\text { impossible to work out. }\end{array}$ & $\begin{array}{l}\text { I am a Christian and I } \\
\text { believe that God decides } \\
\text { our personalities }\end{array}$ \\
\hline $\begin{array}{l}\text { One day science will } \\
\text { be able to predict } \\
\text { how a person will } \\
\text { behave at every } \\
\text { moment }\end{array}$ & $\begin{array}{l}\text { At the rate technology is } \\
\text { advancing, I wouldn't be } \\
\text { surprised } \\
\text { How we behave comes from } \\
\text { how we react to } \\
\text { situations coming from } \\
\text { our brains so if we fully } \\
\text { understand brains, we } \\
\text { will be able to predict } \\
\text { how a person will } \\
\text { behave. }\end{array}$ & $\begin{array}{l}\text { People who do spontaneous } \\
\text { actions are likely to } \\
\text { interrupt what a scientist } \\
\text { predicts them to do, if we } \\
\text { predict someone to do } \\
\text { something, they may } \\
\text { have } 1000 \text { other things } \\
\text { they may want to do } \\
\text { instead. However, we } \\
\text { could predict that the } \\
\text { person will do something } \\
\text { spontaneous, but that's } \\
\text { quite a broad spectrum of } \\
\text { what exactly the action } \\
\text { may be. }\end{array}$ & $\begin{array}{l}\text { I think that the way people } \\
\text { behave in situations is } \\
\text { subjective. Science can } \\
\text { explore it but everyone is } \\
\text { different and behaviour } \\
\text { can be changed instantly } \\
\text { with a change in thought. }\end{array}$ \\
\hline $\begin{array}{l}\text { A person's behaviour } \\
\text { is something that } \\
\text { science will never } \\
\text { be able to fully } \\
\text { explain }\end{array}$ & $\begin{array}{l}\text { Emotion such as love, } \\
\text { anger, sadness and } \\
\text { jealousy are not } \\
\text { scientific, and I don't } \\
\text { think ever will be. It } \\
\text { comes back to the idea of } \\
\text { a soul and a conscience, } \\
\text { they are a huge part of } \\
\text { behaviour. }\end{array}$ & $\begin{array}{l}\text { To some extent science can } \\
\text { explain human } \\
\text { behaviour, e.g. measuring } \\
\text { brain waves, but I think } \\
\text { that something that is so } \\
\text { in depth such as this can } \\
\text { never be fully explained } \\
\text { via scientific equipment. }\end{array}$ & $\begin{array}{l}\text { Science will constantly } \\
\text { improve and get better, I } \\
\text { am confident in the fact } \\
\text { that science will find a } \\
\text { way to explain it }\end{array}$ \\
\hline $\begin{array}{l}\text { Humans can make } \\
\text { choices about how } \\
\text { to behave }\end{array}$ & $\begin{array}{l}\text { Choices are not made by our } \\
\text { DNA. Someone chooses } \\
\text { to be a good or a bad } \\
\text { person, it is not } \\
\text { genetically encoded. }\end{array}$ & $\begin{array}{l}\text { They can have free will but } \\
\text { it should follow some } \\
\text { kind of law. }\end{array}$ & $\begin{array}{l}\text { Our behaviour is } \\
\text { programmed in our } \\
\text { DNA. }\end{array}$ \\
\hline $\begin{array}{l}\text { Human brains are } \\
\text { like computers, } \\
\text { they run on } \\
\text { programs. }\end{array}$ & $\begin{array}{l}\text { Science has proved that } \\
\text { various components have } \\
\text { to 'click' in order for us to } \\
\text { interpret actions and } \\
\text { make decisions. }\end{array}$ & $\begin{array}{l}\text { Brains aren't like computers. } \\
\text { If they were, then } \\
\text { wouldn't we all be } \\
\text { robots? }\end{array}$ & $\begin{array}{l}\text { Computers are always } \\
\text { programmed to do certain } \\
\text { things, whereas the } \\
\text { human brain has no clear } \\
\text { programming, and as a } \\
\text { person can choose their } \\
\text { actions, relies on morals } \\
\text { to make the correct } \\
\text { decisions. } \\
\text { I think that although the } \\
\text { human brain does run in } \\
\text { a certain way, people can } \\
\text { be very surprising } \\
\text { sometimes, and do things } \\
\text { or think things that } \\
\text { normally they wouldn't. }\end{array}$ \\
\hline
\end{tabular}


are your own person" (M-26). There are also a significant number of students who agree that humans make choices and who then use their comment to attribute choice to something the brain does - such as, "they have a brain" (M-7), "their brain controls the emotions that the person feels" (M-9); "Yes, as humans are more than capable to make decisions because of their brains" (M-33). This deserves attention because it highlights that when some students interpret the phrase, "can make choices" they do so through a framework that sees these 'choices' as the inevitable outcomes of brain activity. We concluded that the statement that humans have choices about how they behave generates useful qualitative data but cannot be used to systematically discern students' positions.

Analysis of the survey shows that just over one in four students strongly agreed or agreed that "Human brains are like computers - they run on programs" while fewer than half disagreed or strongly disagreed. One student who agreed commented that:

I think that the majority of decisions we make are very much like programs, programs evolved from our experiences (M-186).

A student who disagrees provides this comment,

There are things that are built deep into our psyche that tell us what is right or wrong in society etc (that you learn in early life) but we do have the choice to 'override' these processes. (M-214)

Some other students disagree and in their comments and refer to an impulsive/random aspect of human behaviour that we noted previously:

In a sense, they do, because they use thought processes to work things out, but on the other hand, they are completely random in their structure. (M-119)

Nearly $60 \%$ of the cohort (58.9\%) strongly agreed or agreed with the statement "The brain is what makes you, 'you'". Most students who strongly agreed or agreed did not give a reason. Some students who strongly agreed or agreed with the statement added a comment which is consistent with scientism, such as: "we are just a brain with a body around us" (M-113); "your brain shows how you act as your brain processes everything that everyone says" (M-9); "Your brain is a computer running a program (your DNA). What makes you 'you' is a combination of the power of the computer and how well programmed your DNA is" (M-133);. Many of the comments are difficult to categorise, such as "We are what we are because of what we think and remember" (M-78). Further there are some students who agree with the statement and who then made a comment that seems more in tune with a nonscientistic position such as, "My mind dictates my attitude" or "free will makes you who you are" (M-150).

Reasons given for rejecting the statement were analysed as follows. Some comments were deemed nonscientistic, such as, "your soul and your brain" (M-163); "The spirit is what makes you" (M-189). There were also students who disagreed with the statement and who explained their response not by saying that humans have something that is inaccessible to scientific enquiry such as mind, spirit or soul, but instead that there are other physical components that also play a part. For example, a student who disagreed, stated that although the brain controls your body, "the genes make you what you are" (M-24) which is an assertion of another scientistic perspective.

Students' comments also reveal that some were struggling to make sense of the ideas in front of them as these examples illustrate. 
I'm unsure about this one. I suppose everything you do is a result of the brain, but I feel uneasy saying that I'm not a person - I'm just a brain in a shell. M-270)

I am unsure whether humans have a soul and whether that affects you rather than your brain. (M-106) I suppose so, if the brain is really where all decisions and thoughts come from but the ability to weigh out pros and cons and emotion I don't think comes from the brain.(M-191)

Table 4 shows the levels of agreement with each of the statements, given in percentages.

\subsection{Feasibility of Grouping Students with Scientistic/Nonscientistic Stances}

Our third research question concerned the feasibility of defining and identifying a group of students who tend to take a scientistic stance across several topics and another group who tend to take a nonscientistic stance? We also wanted to know what else could be drawn from the data about the characteristics of the students in each group.

One objective in this study was to discover whether secondary school students are each consistently scientistic or not scientistic in how they respond to the questionnaire as a whole. We looked for a scale to categorise students into different groups, from strongly scientistic to nonscientistic. We ran a reliability test for the six statements (we did not add the statement about students' interest in this analysis). The questionnaire has a Likert-style format with possible answers ranging from strongly agree to strongly disagree (we removed "I don't understand" responses); each statement stands alone (they do not have interconnections such as "if you agree with the previous question then ..."). With these points in mind, we computed Cronbach's alpha as an index of internal consistency. We reversed the item "A person's behaviour is something that science will never be able to fully explain" in our analysis so that for all statements a low number indicates a more scientistic response. When we first entered all six items into the analysis, the total alpha was 0.535 which is low according to conventional criteria for a scale. We then checked Cronbach's alpha by removing the items one by one and we reached a Cronbach's alpha of 0.716 which is just above the acceptable limit for internal consistency (George and Mallery 2003) when the following three items were included:

Table 4 Level of agreement with survey statements

\begin{tabular}{|c|c|c|c|c|c|c|c|}
\hline & $\begin{array}{l}\text { Strongly } \\
\text { agree }\end{array}$ & Agree & $\begin{array}{l}\text { Neither } \\
\text { agree nor } \\
\text { disagree }\end{array}$ & Disagree & $\begin{array}{l}\text { Strongly } \\
\text { disagree }\end{array}$ & Mean & $\mathrm{SD}$ \\
\hline $\begin{array}{l}\text { I am interested in thinking about what it } \\
\text { means to be human }\end{array}$ & 20.9 & 38.7 & 23.6 & 12.1 & 4.7 & 2.41 & 1.09 \\
\hline The brain is what makes you, 'you' & 19.5 & 39.4 & 24.9 & 12.8 & 3.4 & 2.41 & 1.05 \\
\hline $\begin{array}{l}\text { One day science will be able to tell us } \\
\text { how our personalities are formed }\end{array}$ & 10.2 & 30.5 & 34.2 & 14.9 & 10.2 & 2.84 & 1.10 \\
\hline $\begin{array}{l}\text { One day science will be able to predict } \\
\text { how a person will behave at every } \\
\text { moment }\end{array}$ & 4.0 & 9.1 & 20.1 & 35.2 & 31.6 & 3.81 & 1.01 \\
\hline $\begin{array}{l}\text { A person's behaviour is something that } \\
\text { science will never be able to fully } \\
\text { explain }\end{array}$ & 18.4 & 38.5 & 20.7 & 16.7 & 5.7 & 2.53 & 1.14 \\
\hline $\begin{array}{l}\text { Humans can make choices about how to } \\
\text { behave }\end{array}$ & 38.3 & 45.3 & 10.3 & 4.0 & 2.1 & 1.86 & 0.90 \\
\hline $\begin{array}{l}\text { Human brains are like computers, they } \\
\text { run on programs. }\end{array}$ & 6.7 & 21.2 & 28.6 & 27.3 & 16.2 & 3.25 & 1.16 \\
\hline
\end{tabular}


- One day science will be able to tell us how our personalities are formed.

- One day science will be able to predict how a person will behave at every moment.

- A person's behaviour is something that science will never be able to fully explain.

Three items were removed which were:

- Humans can make choices about how to behave

- Human brains are like computers, they run on programs.

- The brain is what makes you, "you"

There is a high level of agreement with the statement "The brain is what makes you, 'you", a statement which expresses a strongly scientistic (neuro-essentialist) stance. Seen alongside the data we gathered during the interview and focus group studies, these findings indicate that an idea can be popularised and creep into everyday thinking. The statement on making choices prompted different interpretations and illustrates the wider issue of finding ways to introduce philosophical question to students who are not (yet) familiar with philosophical terms. This constraint - to avoid philosophical terms because they are not familiar to studentsparticularly affected our capacity to include positively worded statements. In this survey, most of the research-orientated statements are expressions of scientism.

Working with the mechanism that we now had, we next conducted K-means cluster analysis to see whether the respondents could be organically clustered into three different groups. The results for the cluster analysis using SPSS can be seen in Table 5:

We also ran an ANOVA test to check whether any of the three statements were redundant. As can be seen in the Table 5, the level of significance for all three statements is less than 0.01 , which means that all three statements were useful for clustering. If we aggregate the three items, the score for the first cluster would be 6.15 (possible range 3 to 15 as the total score was the sum of three individual items). This suggests that on average, respondents in this group were inclined to agree or strongly agree with all three scientistic statements. We labelled this group as "strongly scientistic" on the theme of personality and behaviour. The score for the third cluster was 12.83 and we labelled them as nonscientistic. The middle group with the score of 9.99 were labelled as neither strongly scientistic nor nonscientistic.

Twenty percent of the students in the cohort were strongly scientistic on this topic, whereas just over $30 \%$ of students in this cohort were nonscientistic. More than half $(54.3 \%)$ of the strongly scientistic respondents on this topic also strongly agreed or agreed with the statement that "human brains are like computers, they run on programs", and less than $30 \%$ of them disagreed or strongly disagreed with the statement.

Nearly $50 \%$ of students were neither strongly scientistic nor nonscientistic. The analysis of their responses to the range of topics shows that there are scientistic trends in many of their responses. More than half of the respondents in this group strongly agreed or agreed that our personality will be explained by science (one of the criteria for scientism in the rubric) and only three out of 135 respondents in this group disagreed that personality is explainable by science, which is a scientistic view (nobody in this group strongly disagreed with the statement). In the comments entered by these students, many point to the complexity of our brain or other bodily processes as reasons for unpredictability. Here are some examples: "because we can't unlock the science behind the brain" (M-135); "a human brain is hard to predict ..." (M-134); "our brain is too complex ... some people may have mental problems" (M-116); and "...human body is too complex to be able to predict each time" (M-142). 
Table 5 Cluster analysis and ANOVA test results

Final cluster centres

\begin{tabular}{|c|c|c|c|c|c|c|}
\hline & \multicolumn{6}{|l|}{ Cluster } \\
\hline & 1 & \multicolumn{2}{|l|}{2} & \multicolumn{3}{|l|}{3} \\
\hline $\begin{array}{l}\text { One day science will be able to tell us how } \\
\text { our personalities are formed }\end{array}$ & 1.84 & \multicolumn{2}{|c|}{2.48} & \multicolumn{3}{|l|}{4.09} \\
\hline $\begin{array}{l}\text { One day science will be able to predict how } \\
\text { a person will behave at every moment }\end{array}$ & 2.47 & \multicolumn{2}{|c|}{3.81} & \multicolumn{3}{|l|}{4.65} \\
\hline $\begin{array}{l}\text { Reverse of the statement: A person's behaviour is } \\
\text { something that science will never be able to fully } \\
\text { explain }\end{array}$ & 1.84 & \multicolumn{2}{|c|}{3.70} & \multicolumn{3}{|l|}{4.09} \\
\hline \multicolumn{7}{|l|}{ Number of cases in each cluster } \\
\hline \multirow[t]{3}{*}{ Cluster } & 1 & & 57.000 & & & \\
\hline & 2 & & 135.000 & & & \\
\hline & 3 & & 88.000 & & & \\
\hline \multirow{4}{*}{$\begin{array}{l}\text { Valid } \\
\text { Missing } \\
\text { ANOVA }\end{array}$} & & & 280.000 & & & \\
\hline & & & 31.000 & & & \\
\hline & Cluster & & Error & & $F$ & Sig. \\
\hline & $\begin{array}{l}\text { Mean } \\
\text { square }\end{array}$ & $d f$ & $\begin{array}{l}\text { Mean } \\
\text { square }\end{array}$ & $d f$ & & \\
\hline $\begin{array}{l}\text { One day science will be able to tell us how } \\
\text { our personalities are formed }\end{array}$ & 105.865 & 2 & .500 & 277 & 211.646 & .000 \\
\hline $\begin{array}{l}\text { One day science will be able to predict how } \\
\text { a person will behave at every moment }\end{array}$ & 81.759 & 2 & .640 & 277 & 127.746 & .000 \\
\hline $\begin{array}{l}\text { Reverse of the statement: A person's behaviour } \\
\text { is something that science will never be able to fully } \\
\text { explain }\end{array}$ & 95.843 & 2 & .619 & 277 & 154.892 & .000 \\
\hline
\end{tabular}

\section{Conclusion}

This study sought to discover the feasibility of a survey to draw from students a range of responses about the power and limitations of science in relation to the Big Question of human personhood. During the interviews and workshops we found that most students were unfamiliar with philosophical terms and expressed their ideas in everyday or scientific language. We identified six statements that can be presented to students in a questionnaire to prompt them to reflect on the power and limitations of science in this broad theme. The responses from 311 secondary students revealed that they are engaged by the Big Question and that across a subset of topics, they take a range of stances from strongly scientistic to nonscientistic. We also found that comments, ideas and phrases associated with scientism were expressed by the majority of students at different points. Scientistic phrases are present in everyday language and there was widespread agreement across the groups with the statement, "the brain is what makes you you". There are also comments by students in the cohort which seem to resist this position and also comments which suggest that many students are wrestling with what to believe.

One of our three research questions was to discover if it is feasible to categorise individual students' stances as scientistic or nonscientistic. Students' responses to the survey indicate that they are generally not thinking within an overarching scientistic or nonscientistic framework. 
When we found a way to categorise students, it was by reducing the spread of topics to three statements on personality and behaviour and having applied this method of categorisation we found a degree of resonance in the ways that students respond to other statements in the survey.

Science curricula in England (DfE 2014) and internationally (ACAPA 2011; Hansson and Redfors 2007b) suggest that formal education has a role to play in ensuring that students have opportunities to critically examine the nature of science. Analysis of these students' comments reveals that they are trying to make sense of a myriad of ideas including what their intuition tells them, what they perceive science teachers to say and ideas they have held growing up. It seems likely that different statements trigger different conversations and situations for them. With this said, the findings of this study highlight the need for researchers and teachers to develop pedagogies to increase students' criticality and their familiarity with the language associated with metaphysical and epistemological discourse. By the rubric we used here for grouping students, one in five of the cohort were found to be strongly scientistic in their perception of the explanatory and predictive power of science in the context of personality and behaviour. This was a strong form of scientism; for example, the majority of students in this group did not reject the idea that science can one day predict behaviour at every moment. Students who were categorised as nonscientistic using the statements on personality and behaviour sometimes slipped into scientistic language. Overall, we found that students are making connections between the constructs they learn about in science and the bigger metaphysical questions of personhood and the nature of reality. We discovered that there is a tendency among upper-secondary students to express ideas that reflect strongly scientistic stances and that students can be categorised to an extent according to the stances they express. Comments by students revealed many instances where they associated the scientific position with scientism and further felt this to be in conflict or in tension with their own position.

\section{Recommendations for Teaching and Further Research}

The motivation for this project was to identify ways that schools can develop students' epistemic insight when they consider Big Questions and the power and limitations of science. The project as a whole aimed to produce questionnaires, focus groups and interview schedules and workshops that could be used for this purpose in teaching and research. This study plays a key part by establishing language and topics that work well with students in upper secondary school to engage their interest and prompt discussion about the power and limitations of science. Teachers and researchers can use the questionnaire statements to discover students' stances and inform a class discussion or follow-up interview study. Based on our studies to date we recommend interviews and workshops as the most appropriate ways to investigate and advance students' insight into a range of stances and arguments that relate to their own positions. Further research could extend the survey to include other topics and could compare the responses from upper secondary school students with those from other age groups.

The findings from this cohort of students support the case that students need opportunities to think critically about their own stances and the messages they encounter. We recommend that students have teaching by science specialist teachers about the power and limitations of science in the context of what science says about human personhood. Introducing students to a selection of scholarly positions would help ensure they do not come to see one view as being a norm or consensual view. It would also counter uncritical scientism and familiarise students with philosophical language. These sessions would be focused on exploring questions about 
science and could take place in a philosophy or religious education classroom or general area such as a library. Teachers in the humanities would ideally also provide input and the session could be characterised to students as similar to the scenario of a scientist leaving the lab and thinking about the wider implications of the findings with scientists and other scholars.

Previous studies have noted that teachers are often reluctant to talk about questions that extend beyond the boundaries of science (Lederman et al. 2014). As Hansson and Redfors (2007a) pointed out, however, maintaining a silence about these issues is potentially more problematic, for by saying nothing about the difference between science and scientism, students may be left to make unintended inferences. This study forms part of a larger project that is exploring ways to counter uncritical scientism and teach epistemic insight. We have begun to design and test workshops that respond to the findings of this study. The aim is to develop strategies to equip students with key terms which they can use to express and critically examine their own and other people's stances on the power and limitations of science. These include human personhood, nature of reality and metaphysics The workshops are also designed to develop students' appreciation and understanding that, "some questions are more amenable to science than others", that "scientism is not a necessary presupposition of science" and that "some questions are more metaphysically sensitivity than others". One school hosting a pilot workshop organised an evaluation and sent us a report of students' feedback along with an anonymised comment by a student on what he/she had found out. The comment illustrated a student in our target age group (age 13-15) using terms taught in the session. It also illustrated the value of a session that provided students with an opportunity to critically examine a range of stances on the power and limitations of science:

That depending on your metaphysical position, your opinions and furthermore answers to certain questions vary. It was awesome, my favourite [workshop] by far. [...] It opened my eyes a lot to the opinions of others and as to what metaphysics is about.

Acknowledgements We would like to thank the staff and students in the schools who contributed to this study. The study reported in this paper derives from the "Being Human" research project at the Learning about Science and Religion (LASAR) Research Centre. The project is supported by the Templeton World Charity Foundation, grant number TWCF0192.

\section{Compliance with Ethical Standards}

Conflict of Interest The authors declare that they have no conflict of interest.

OpenAccess This article is distributed under the terms of the Creative Commons Attribution 4.0 International License (http://creativecommons.org/licenses/by/4.0/), which permits unrestricted use, distribution, and reproduction in any medium, provided you give appropriate credit to the original author(s) and the source, provide a link to the Creative Commons license, and indicate if changes were made.

Publisher's Note Springer Nature remains neutral with regard to jurisdictional claims in published maps and institutional affiliations.

\section{References}

Abrahams, I., \& Millar, R. (2008). Does practical work really work? A study of the effectiveness of practical work as a teaching and learning method in school science. International Journal of Science Education, 30(14), 1945-1969. ACAPA. (2011). National science curriculum. Australian Curriculum, Assessment and Reporting Authority. 
Alexander, D. (2013). Genes, determinism and God: Discussion. In B. White (Ed.). Cambridge: The Faraday Institute for Science and Religion.

Atkins, P. W. (1995). The limitless power of science. In J. Cornwell (Ed.), Nature's imagination: The frontiers of scientific vision (pp. 122-132). Oxford: Oxford University Press.

Babakus, E., \& Mangold, W. G. (1992). Adapting the SERVQUAL scale to hospital services: An empirical investigation. Health Services Research, 26(6), 767.

Bernstein, B. (2000). Pedagogy, symbolic control and identity: Theory, research and critique. Revised edition. Oxford: Rowman and Littlefield Publishers.

Billingsley, B. (2013). Students' reasoning about personhood, being human and the soul. Paper presented at the Bristol Theological College. Bristol: Seminar Programme.

Billingsley, B. (2017). Teaching and learning about epistemic insight. School Science Review, 98(365), 59-64.

Billingsley, B., Abedin, M., \& Chappell, K. (2018). A Teacher's guide to science and religion in the classroom. Routledge.

Billingsley, B., Brock, R., Taber, K. S., \& Riga, F. (2016). How students view the boundaries between their science and religious education concerning the origins of life and the universe. Science Education, 100(3), 459-482.

Billingsley, B., \& Hardman, M. (2017). Epistemic insight: Teaching and learning about the nature of science in real-world and multidisciplinary arenas. School Science Review, 98(365), 57-58.

Billingsley, B., \& Nassaji, M. (2017). Ways to develop Students' appreciation of the power and limitations of science In G. Straine (Ed.), Are There Limits to Science? (pp. 154-165). Cambridge: Cambridge Papers.

Billingsley, B., Riga, F., Taber, K. S., \& Newdick, H. (2014). Secondary school teachers' perspectives on teaching about topics that bridge science and religion. Curriculum Journal, 25(3), 372-395.

Billingsley, B., Taber, K. S., Riga, F., \& Newdick, H. (2013). Secondary school students' epistemic insight into the relationships between science and religion-A preliminary enquiry. Research in Science Education, 43(4), 1715-1732.

Bloom, P. (2004). Natural-born dualists. Edge: The Third Culture Retrieved from https://www.edge. org/conversation/paul_bloom-natural-born-dualists. Accessed 10 December 2018.

Cath, C., Wachter, S., Mittelstadt, B., Taddeo, M., \& Floridi, L. (2018). Artificial intelligence and the 'good society': The US, EU, and UK approach. Science and Engineering Ethics, 24(2), 505-528.

Cheung, A. T. (2018). Including everyone but engaging no one? Partnership as a prerequisite for trustworthiness. The American Journal of Bioethics, 18(4), 55-57.

Colburn, T. (2015). Philosophy and computer science. Routledge.

Crick, F. (1994). The astonishing hypothesis. London: Simon \& Schuster.

DfE. (2014). Science programmes of study: Key stage 4, National Curriculum in England. London: Department of Education Retrieved from https://www.gov.uk/government/uploads/system/uploads/attachment data/file/318384/Science_KS4_PoS_draft_programmes_of_study.pdf. Accessed 10 December 2018.

Duschl, R. A., \& Osborne, J. (2002). Supporting and promoting argumentation discourse in science education.

Freeman, C. (2002). Scientists prove chocolate 'better than being in love. Retrieved from http://www.dailymail. co.uk/news/article-128858/Scientists-prove-chocolate-better-love.html\#ixzzlnawzmO00. Accessed 10 December 2018.

Fuchs, T. (2004). Neurobiology and psychotherapy: An emerging dialogue. Current Opinion in Psychiatry, $17(6), 479-485$.

George, D., \& Mallery, P. (2003). Reliability analysis. SPSS for Windows, step by step: a simple guide and reference (14th ed.pp. 222-232). Boston: Allyn \& Bacon.

Grossi, G. (2017). Hardwiring: Innateness in the age of the brain. Biology and Philosophy, 32(6), 1047-1082.

Hansson, L., \& Redfors, A. (2007a). Physics and the possibility of a religious view of the universe: Swedish upper secondary students' views. Science \& Education, 16, 461-478.

Hansson, L., \& Redfors, A. (2007b). Upper secondary students in group discussions about physics and our presuppositions of the world. Science \& Education, 1007-1025.

Harris, S. (2012). Free will. Simon and Schuster.

Hawkins, S. (2017). Year 8 topics studied in Science Retrieved from www.sgschool.org.uk/force_download. $\mathrm{cfm}$ ? id=1025. Accessed 10 December 2018.

Hayward, J. L. (1998). The creation/evolution controversy: An annotated bibliography. Lanham: Scarecrow Press.

Jamieson, A., \& Radick, G. (2013). Putting Mendel in his place: How curriculum reform in genetics and counterfactual history of science can work together. In K. Kampourakis (Ed). The Philosophy of Biology: A Companion for Educators. (pp. 577-595): Springer.

Kidd, I. J. (2016). Is scientism epistemically vicious. Scientism: Problems and Prospects.

Konnemann, C., Asshoff, R., \& Hammann, M. (2016). Insights into the diversity of attitudes concerning evolution and creation: A multidimensional approach. Science Education, 100(4), 673-705. 
Kötter, M., \& Hammann, M. (2017). Controversy as a blind spot in teaching nature of science. Science \& Education, 26(5), 451-482.

Lederman, N. G., Antink, A., \& Bartos, S. (2014). Nature of science, scientific inquiry, and socio-scientific issues arising from genetics: A pathway to developing a scientifically literate citizenry. Science \& Education, 23, $285-302$.

Lewis, J., \& Kattmann, U. (2004). Traits, genes, particles and information: Re-visiting students' understandings of genetics. International Journal of Science Education, 26(2), 195-206.

Longshaw, S. (2009). Creativity in science teaching. School Science Review, 90(332), 91-94.

Mansell, W. (2016). Press release-Most teenagers "believe they have a soul" [Press release]. Retrieved from https:/www.bera.ac.uk/bera-in-the-news/press-release-most-teenagers-believe-they-have-a-soul

Marcus, G. (2015). Face it, your brain is a computer. New York Times, p. SR12. Retrieved from https://www. nytimes.com/2015/06/28/opinion/sunday/face-it-your-brain-is-a-computer.html. Accessed 10 December 2018.

Miller, H. T. (2015). Scientism versus social constructionism in critical policy studies. Critical Policy Studies, 9(3), 356-360.

Murphy, N., \& Brown, W. (2007). Did my neurons make me do it? : Oxford University Press Oxford.

Osborne, J. (2013). The 21 st century challenge for science education: Assessing scientific reasoning. Thinking Skills and Creativity, 10, 265-279.

Osborne, J., \& Collins, S. (2001). Pupils' views of the role and value of the science curriculum: A focus-group study. International Journal of Science Education, 23(5), 441-467.

Paton, G. (2013). GCSE results 'influenced by children's genes, not teaching'. The telegraph. Retrieved from http://www.telegraph.co.uk/education/educationnews/10200429/GCSE-results-influenced-by-childrensgenes-not-teaching.html. Accessed 10 December 2018.

Polkinghorne, J. (2004). The person, the soul, and genetic engineering. Journal of Medical Ethics, 30(6), 593597.

Polkinghorne, J. (2006). Space, time. and causality. Zygon, 41(4), 975-984.

Racine, E., Waldman, S., Rosenberg, J., \& Illes, J. (2010). Contemporary neuroscience in the media. Social Science \& Medicine, 71(4), 725-733.

Roberts, M. (2016). New blood test targets depression. BBC news. Retrieved from http://www.bbc.co. uk/news/health-36459679. Accessed 10 December 2018.

Sandoval, W. A. (2016). Disciplinary insights into the study of epistemic cognition. In Jeffrey A. Greene, William A. Sandoval, Ivar Bråten (Eds) Handbook of epistemic cognition, New York: Routledge. 184.

Spencer, B. (2015). Scan that says it's true love: Brain experts say they can tell what stage of romance someone is at by looking at MRI results. Daily Mail. Retrieved from http://www.dailymail.co.uk/sciencetech/article2995741/The-scan-says-s-true-love.html. Accessed 10 December 2018.

Stenger, V. J. (2007). God: the failed hypothesis: how science shows that god does not exist: Prometheus books.

Stenmark, M. (1997). What is scientism? Religious Studies, 15-32.

Taber, K. S. (2009). Progressing science education: Constructing the scientific research programme into the contingent nature of learning science. Dordrecht: Springer.

Tho, S. W., \& Yeung, Y. Y. (2016). Technology-enhanced science learning through remote laboratory: System design and pilot implementation in tertiary education. Australasian Journal of Educational Technology, $32(3)$.

Van Fraassen, B. C. (2008). The empirical stance. Yale University Press.

Van Inwagen, P. (2018). Metaphysics. Routledge.

Waghorn, M. (2016). Scientists discover 'chatty' gene that makes people sociable in breakthrough that could help treat autism. Daily Mirror. Retrieved from http://www.mirror.co.uk/news/uk-news/scientists-discover-chattygene-makes-8239758. Accessed 10 December 2018.

White, R. T., \& Gunstone, R. F. (1992). Probing Understanding. London: Falmer Press.

Wysong, R. L. (1976). The Creation-evolution Controversy:(implications, Methodology and Survey of Evidence): Toward a Rational Solution. Wysong: Wysong Institute.

Zhai, J., Jocz, J. A., \& Tan, A.-L. (2014). ‘Am I like a scientist?': Primary children's images of doing science in school. International Journal of Science Education, 36(4), 553-576. 